\title{
Stranger than fiction
}

\section{The tale of the epic voyage made to establish the metric system is an intriguing and exciting one.}

\section{Julyan Cartwright}

W ho thinks about science during a vacation on the Balearic Islands? Majorca, Minorca, Ibiza and Formentera are holiday destinations par excellence, not places where famous scientists of the past lived and worked, or where great experiments were carried out. But there was a moment in history when the Balearic Islands were crucial for a major scientific undertaking.

It was 1806, and the French Bureau des Longitudes had the task of determining the Paris meridian - the line of longitude passing through Paris. At the time there was no universally agreed prime meridian; it wasn't until 1884 that an international congress decided it should be the one that passes through Greenwich. The reason for determining the meridian with precision wasn't map-making but the metric system. A few years earlier, French revolutionaries had decided to come up with a new, rational system of measurement. The metre, the new base unit of length, was to be defined as one ten-millionth of the distance from Pole to Equator along the Paris meridian. So it was very important to know exactly how long this meridian was.

A first series of measurements, from Dunkirk to Barcelona, came up with a provisional value for the length and a prototype metre bar was produced. Two young physicists, François Arago and Jean-Baptiste Biot, were given the task of checking and improving the accuracy of this result by extending the observations to the Balearic Islands. Arago and Biot had to light a bonfire on a mountain peak and attempt to view this at night from another peak to obtain their triangulation readings.

South from Paris, the meridian first passes Barcelona on the coast of the Spanish mainland and then runs close to Majorca, more than $200 \mathrm{~km}$ away across the Mediterranean Sea. This was too great a distance to make direct observations, so Biot and Arago took triangulations from mountain tops down the Spanish coast to Denia, then across the shorter stretch of sea from there to Ibiza and Formentera - still a difficult task with visual observations - and then finally to Majorca. On Ibiza they used the mountain Camp Vey, and on Formentera, the highest point on the island, La Mola. At the end of 1807, Biot returned to Paris with the observations from Ibiza and Formentera, and left
Arago alone to complete the final readings from Majorca. On Majorca, Arago chose S'Eslop, a peak on the northwest coast, as his viewpoint of Ibiza and Formentera. He had a hut built on the summit and settled in with his instruments for the final series of measurements. But events didn't go according to plan.

War broke out between France and Spain in June 1808, while Arago was on the summit of S'Eslop. Soon Majorcans were commenting that the nightly bonfires were signals and that Arago must be a French spy, and a detachment of soldiers was sent up the mountain to capture him. Arago got wind of this; in his memoirs, he recounts what happened next: "We set off for Palma and we encountered the troops that had come to look
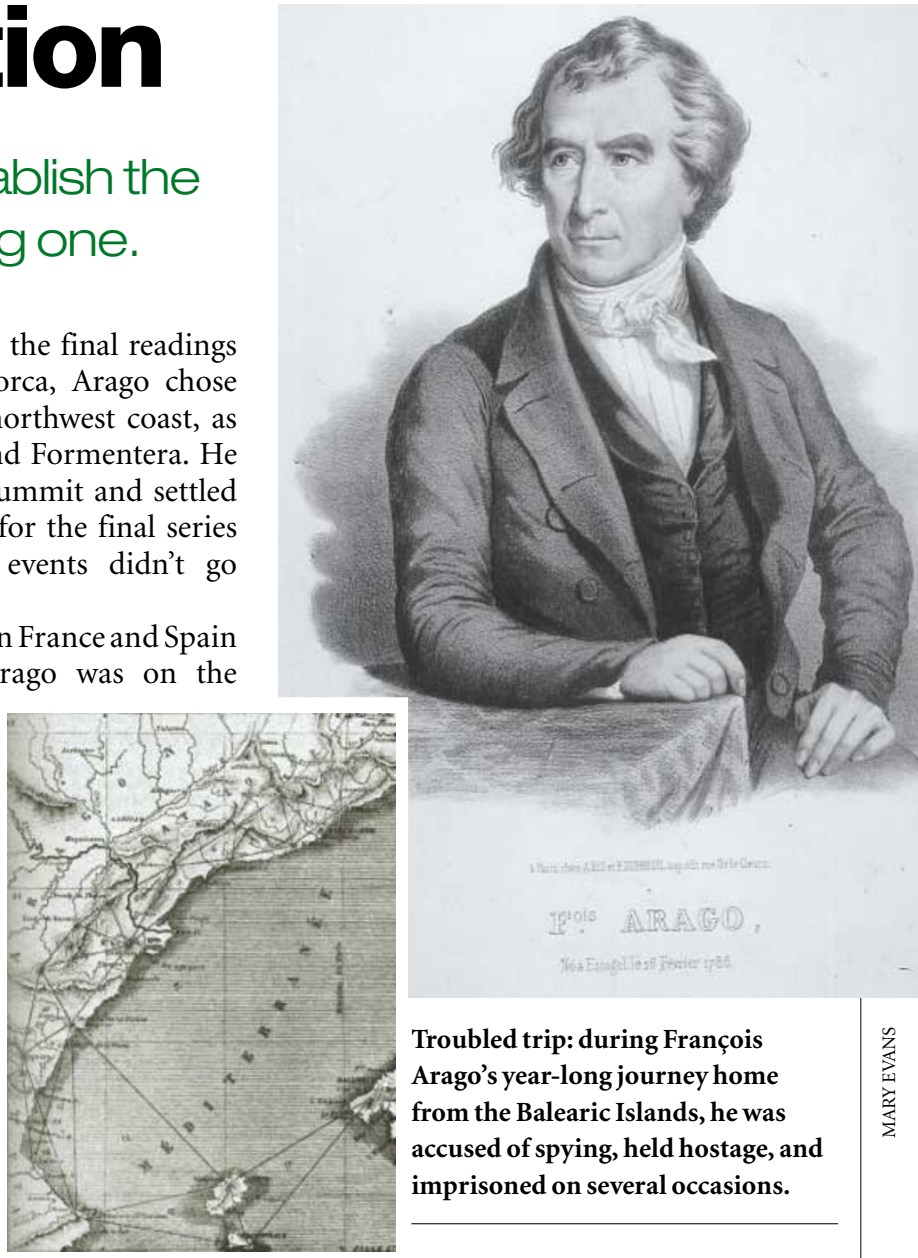

for me. Nobody recognized me because I spoke Mallorquin perfectly. I urged the platoon to continue on the path, and we continued on our route towards the city." (Arago spoke Mallorquin, a version of Catalan, as he was born in the French Pyrenees, a Catalan-speaking region of France.) His escape was only temporary, though - he eventually ended up in Bellver Castle, overlooking Palma de Majorca. Now a tourist attraction, it was then a prison.

In the end, Arago managed to persuade the authorities that he wasn't a spy, and left the island for Algiers. From there he took a ship headed for Marseilles, but his bad luck continued - the ship was intercepted by Spanish pirates and escorted to Catalonia, where he was again imprisoned. Once more, he got himself released, and again set sail for Marseilles. This time it was not pirates but bad weather that intervened it was now December 1808. The ship was forced by a storm to land at a small port in Algeria and was unable to make the winter crossing to Marseilles, so Arago headed back overland to Algiers. Here he was held captive again, this time as a hostage by the Algerians until the French paid for goods sent to France.

This was resolved in July 1809, and after a year-long odyssey, Arago finally arrived back in France to file his scientific reports, and received a triumphal reception in Paris. Arago and Biot's labours confirmed the accuracy of the original measurements; in the end, the prototype metre differed from the original meridian definition by just $0.02 \%$.

Arago became an eminent physicist, making many important discoveries in optics (Arago's spot) and electromagnetism (Arago's disc). He later entered politics, becoming Minister of War and the Navy, and he abolished slavery in French territories. Biot too became a physicist of note; his bestknown contribution is the Biot-Savart law in electromagnetism.

Today, Arago is honoured in Paris with the Arago monument: a trail of plaques let into the pavements of the city to mark the path of the meridian he plotted. His adventures in the Balearics were fictionalized by his friend Jules Verne, who mentions these episodes in his novels set in the Balearic Islands, Clovis Dardentor and Hector Servadac (Off on a Comet, in its English translation). On Formentera, this fiction is remembered more clearly than the reality, because on La Mola stands a monument not to Arago and Biot, but to Verne, who probably never visited the islands.

Julyan Cartwright is at the Laboratory for

Crystallographic Studies, CSIC,

E-18071 Granada, Spain. 